\title{
Distribution of hepatitis B virus genotypes in the general population of Myanmar via nationwide study
}

Yi Yi Kyaw ${ }^{1,3}$, Aye Aye Lwin², Khin Saw Aye ${ }^{2}$, Hlaing Myat Thu², Moh Moh Htun², Hnin Ohmar Soe ${ }^{1}$, Kay Thi Aye?', Kyaw Zin Thant ${ }^{2}$, Hyeon Jeong Hwang ${ }^{3}$ and JaeHun Cheong ${ }^{3^{*}}$

\begin{abstract}
Background: Hepatitis B virus (HBV) infections are a severe health concern worldwide. HBV is a DNA virus with a rapid rate of mutation. Based on heterogeneity of the nucleotide sequence, the HBV strains are divided into nine genotypes, each with a characteristic geographical distribution. Identifying and tracking alterations of HBV genotypes is important in epidemiological and transmission studies, and contributes to predicting the risk for development of severe liver disease and response to antiviral treatment. The present study was undertaken to detect HBV genotypes and sub-genotypes in the general population of different states and regions in Myanmar.

Methods: In 2015, a total of 5547 adults of the general population, residing in seven states, seven regions and the Nay Pyi Taw Union Territory, were screened for Hepatitis B Surface antigen (HBsAg) by the immunochromatographic test (ICT). Of the $353 \mathrm{HBsAg}$ positive samples, the HBVDNA was identified using polymerase chain reactions (PCR) targeting the DNA sequences encoding the Pre-S region. A total of 153 PCR positive samples were subsequently subjected to genotyping by partial genome sequencing in both directions. The resulting sequences were then edited, aligned, and compared with reference sequences using the National Centre for Biotechnology Information (NCBI) web-based genotyping tool.

Results: Three HBV genotypes (HBV genotype B, genotype C and genotype D) were detected in Myanmar, of which genotype HBV genotype C (66.7\%) was the most prevalent, followed by HBV genotype D (32\%) and HBV genotype $B(1.3 \%)$. Sub-genotyping revealed a total of 7 variants within the $B, C$ and $D$ genotypes: 2 (B4 and B5) in HBV genotype $\mathrm{B}, 3$ (C1, C5 and C7) in HBV genotype $C$, and 2 (D3 and D6) in HBV genotype D.

Conclusion: HBV genotype $C$, sub-genotype $C 1$ was predominantly distributed in all states and regions of Myanmar. This study is the first report on the nationwide distribution of HBV genotypes and sub-genotypes in Myanmar. We believe our findings will enable huge support for the hepatitis disease surveillance program, since HBV infection is one of the National Priority Diseases in Myanmar.
\end{abstract}

Keywords: Hepatitis B virus, Genotype, Sub-genotype, Myanmar

* Correspondence: molecule85@pusan.ac.kr

${ }^{3}$ Department of Molecular Biology, Pusan National University, Busan 46241, Republic of Korea

Full list of author information is available at the end of the article

(c) The Author(s). 2020 Open Access This article is licensed under a Creative Commons Attribution 4.0 International License, which permits use, sharing, adaptation, distribution and reproduction in any medium or format, as long as you give appropriate credit to the original author(s) and the source, provide a link to the Creative Commons licence, and indicate if changes were made. The images or other third party material in this article are included in the article's Creative Commons licence, unless indicated otherwise in a credit line to the material. If material is not included in the article's Creative Commons licence and your intended use is not permitted by statutory regulation or exceeds the permitted use, you will need to obtain permission directly from the copyright holder. To view a copy of this licence, visit http://creativecommons.org/licenses/by/4.0/ The Creative Commons Public Domain Dedication waiver (http://creativecommons.org/publicdomain/zero/1.0/) applies to the data made available in this article, unless otherwise stated in a credit line to the data. 


\section{Background}

The Hepatitis B virus (HBV) belongs to the genus Orthohepadnavirus of the Hepadnaviridae family and its liver infection can cause both acute and chronic diseases. Globally, an estimated 257 million people are living with hepatitis B virus (HBV) infection. In 2015, hepatitis B infection resulted in 887,000 deaths, mostly from complications that include cirrhosis and hepatocellular carcinoma [1]. In the same year, the World Health Organization (WHO) estimated that the global prevalence of $\mathrm{HBV}$ infections in the general population was $3.5 \%$. The proportion of persons living with chronic HBV infection remains high among those born before availability of the hepatitis $B$ vaccine. Prevalence was the highest in the African (6.1\%) and Western Pacific regions (6.2\%), followed by Asia (2\%) [2]. Myanmar has a moderate to high endemicity of hepatitis B infection. According to the nationwide seroprevalence survey in $2015,6.5 \%$ of the general population was infected with viral hepatitis $\mathrm{B}$. The prevalence varied with geographic locations, with highest prevalence in the Yangon Region (10\%) and lowest in Kayah State (4.2\%) [3].

$\mathrm{HBV}$ is a circular DNA molecule of approximately 3.2 $\mathrm{k}$ base pairs; it is a partially double-stranded DNA that replicates through an RNA intermediate anti-genome sequence, using its own encoded reverse transcriptase (RT). Since HBV-RT is lacking in a proof-reading function, there are occurrences of error frequencies, and these error-prone conditions are similar to those encountered in retroviruses and other RNA viruses [4]. Persistent and long-term infections, and different selected pressures on viruses, has resulted in the emergence of HBV variants. Some of the variants are able to evade diagnostics as well as prophylactic and therapeutic measures. The HBV genome encodes viral proteins through four open and partially overlapping reading frames: surface (preS/S), core (preC/C), polymerase $(\mathrm{P})$, and $\mathrm{X}$ genes. These genes encode for specific proteins: preC/C, for the e antigen ( $\mathrm{HBeAg}$ ) and core protein (HBcAg); P gene, for polymerase (reverse transcriptase); $\mathrm{S}$ gene, for surface proteins (there are three forms of HBsAg: small (S), middle (M) and large (L)); and X gene, for a transcriptional transactivator protein $[5,6]$.

Based on the genome sequence, HBV is grouped into numerous genotypes, of which 9 genotypes are welldefined. Some HBV genotypes are further classified as sub-genotypes. The HBV sequence is characterized by having more than $8 \%$ nucleotide differences for genotypes, and more than 4-8\% nucleotide differences for subgenotypes. To date, over 30 related sub-genotypes belonging to HBV genotypes have been determined [7, 8].

An earlier classification system divided the HBsAg into four major serological subtypes, viz., $a d w, a d r$, $a y w$ and ayr, which, in turn, are correlated to HBV genotypes. In general, $\mathrm{HBV}$ genotypes of $\mathrm{A}, \mathrm{B}, \mathrm{F}, \mathrm{G}$ or $\mathrm{H}$ have the HBsAg subtype $a d w$, whereas HBV genotype $C$ have $a d r$, and HBV genotype D and HBV genotype $\mathrm{E}$ have ayw $[9,10]$. Genotypes A and D are globally distributed, whereas genotypes $\mathrm{B}$ and $\mathrm{C}$ are predominantly found in east and southeast Asia, and genotype E prevails in West Africa. The most divergent genotype $\mathrm{F}$ is found exclusively among the indigenous people of central and south America. Genotype G, found in the USA and France, exhibits a unique molecular structure [8].

Myanmar is one of the most ethnically diverse countries, bordered by Bangladesh and India on the western border, China, Laos and Thailand on the eastern border, Thailand on the southern border, and China on the northern border. The major genotype of HBV in China and Thailand is genotype $\mathrm{C}$, while the genotype $\mathrm{D}$ is most prevalent in India [4, 11-14]. There are limited studies in Myanmar on HBV serotypes and genotypes. Previous studies on distribution of HBV serotypes and genotypes in Myanmar were mainly carried out on specific populations. A study in 2012 reported the distribution of HBsAg subtypes among the HBV carriers in Yangon as $a d r$ (93.2\%), adw (4.85\%) and $a y w$ (1.94\%) [15]. A hospital-based study showed HBV genotype $\mathrm{C}$ as the prevalent $\mathrm{HBV}$ genotype in chronic liver disease, followed by HBV genotype A, as well as mixed genotypes and unknown genotypes [16]. Sa-Nguanmoo et al. (2010) also reported the occurrence of HBV genotype C (97.5\%), HBV genotype B and HBV genotype D $(1.25 \%$ each) among Myanmar migrant workers in Thailand [17]. Recently, Latt et al. reported on whole genome sequences of 15 isolates from Myanmar HBV carrier patients, revealing that all were genotype $\mathrm{C}$ with subgenotype C1 [18].

Genotypes and certain sub-genotypes have distinct geographical distribution, and are important in both clinical manifestation of infection and response to antiviral therapy. Moreover, the HBV genotype/sub-genotype and the inherent genetic variability are also useful in epidemiological and surveillance studies, tracing human migrations, predicting the risk of developing severe liver diseases, and responses to antiviral therapy [19]. However, there are no large-scale studies on the geographical distribution of HBV genotypes in Myanmar, and this study is, therefore, the first report on the nationwide distribution of hepatitis $B$ genotypes and subgenotypes.

\section{Methods}

\section{Study site and study population}

From May to October 2015, a cross-sectional survey was conducted in 18 townships of all states and regions of Myanmar. The 18 townships were selected from 7 states (Kachin, Kayah, Kayin, Chin, Mon, Shan and Rakhine), 7 
regions (Bago, Sagaing, Magway, Ayeyarwady, Tanintharyi, Yangon and Mandalay), and the Nay Pyi Taw Union Territory. A total of 5547subjects, aged between 15 to 80 years and belonging to both genders, participated in the survey.

\section{Sampling procedure and recruitment}

To achieve a national representative sample, the twostage cluster sampling method was used. Selection of the primary sampling units (PSUs) was performed by randomly selecting one township, which was considered to have an average level of viral hepatitis B when considering all states and regions of Myanmar. Selection of secondary sampling unit (SSUs) was achieved by selecting 10 wards and villages from each selected PSU township, based on the probability to population size. Systemic random sampling was then used to select 30 households from each selected SSU (ward/village). The sampling frame for the current study included the list of households available to the Basic Health staff. One eligible participant in the selected household, aged between 15 to 80 years, was recruited by random sampling. Informed consent of the participant was obtained by the in-field investigators who explained the purpose and procedure of the study, and it was signed on-site before blood samples were drawn. Hepatitis B virus screening was carried out with the rapid assay SD Bioline HBsAg WB (Cat. No 01FK10W, Standard Diagnostic, Inc., Korea), and results were shared with the participants individually, in a closed envelope. Counseling for consequences of $\mathrm{HB}$ infection, and treatment options and health education was imparted to all positive patients, and a second informed consent form was obtained for genotyping study. All positive patients from sampling sites in Myanmar were invited for a genotyping study without sampling bias [3].

\section{Sample collection for genotyping study}

The field investigators explained the purpose and procedure of the study, and informed consent was obtained from each subject before $2 \mathrm{ml}$ venous blood samples were drawn. Sera were separated and transported to the Department of Medical Research for further genotyping. A total of $353 \mathrm{HBsAg}$ positive subjects, 147 males and 206 females with mean age 35.5 years $(\mathrm{SD}=10.8)$, were included in this genotyping study. The number of samples in this study represents a $99.7 \%$ response rate of the total $354 \mathrm{HBV}$ sero-positive patients confirmed from the nationwide study.

\section{Confirmation of $\mathrm{HBsAg}$ positive serum samples}

Serum samples which tested positive for HBsAg by ICT (Immuno-chromatographic Test) were further confirmed with a commercially available HBsAg ELISA 3.0 immunoassay kit (Cat. No 01EK10, Standard Diagnostic
Test Kit, SD, Korea). The tests were performed according to the manufacturer's instruction.

\section{Viral DNA extraction}

Serum samples confirmed HBsAg positive by ELISA were subjected to viral DNA extraction, which was achieved with the QIAampDNA Mini kit (Qiagen, Inc., Hilden, Germany), according to the manufacturer's instructions.

\section{Amplification of the preS gene of HBV by PCR}

The HBV preS gene was amplified with nested PCR, using PF-PR and NF-NR primer sets (PF 5' TTG GAC TCA CAA GGT GGG AA 3'; PR 5' GTC CAC CAC GAG TCT AGA CTCT 3'; NF 5' TCA TTT TGT GGG TCA CCA TAT 3'; NR 5' CTG TAA CAC GAG CAG GGG T $3{ }^{\prime}$ ). The primers were located in the preS/S genomic regions to ensure a high sensitivity for amplification of all HBV genotypes. The amplification mixture contained $5 \mu \mathrm{l}$ extracted HBVDNA, Tris HCL buffer, 2 $\mathrm{mM}$ magnesium chloride, $0.1 \mathrm{mM}$ dNTPs, 2 units taq polymerase (Cosmo), and $0.25 \mu \mathrm{M}$ each of the primers. The PCR thermal cycling profile was as follows: $5 \mathrm{~min}$ at $94{ }^{\circ} \mathrm{C}$, followed by 30 cycles comprising $30 \mathrm{~s}$ at $94{ }^{\circ} \mathrm{C}, 30$ $\mathrm{s}$ at $51^{\circ} \mathrm{C}$, and $45 \mathrm{~s}$ at $72{ }^{\circ} \mathrm{C}$, and finally $10 \mathrm{~min}$ at $72^{\circ} \mathrm{C}$. Negative samples after the first round PCR were amplified in nested PCR using the second round primer set and a thermal profile similar to the first round, but repeated for 35 cycles instead of 30 , with annealing at $54{ }^{\circ} \mathrm{C}$. After confirming $578 \mathrm{bp}$ PCR product by gel electrophoresis, the products were purified with the SV column PCR purification kit (GeneAll Biotech, Korea), according to the manufacturer's instructions.

\section{Determination of HBV genotypes by direct sequencing of pres gene}

The purified PCR products were subjected to sequencing by chain termination method, using a commercially available kit (Big DyeTerminator Cycle Sequencing Kit, Applied Biosystems). Briefly, $2 \mu \mathrm{l}$ purified DNA was mixed with $1.85 \mu \mathrm{l} 5 \mathrm{x}$ sequencing buffer, $0.25 \mu \mathrm{l}$ Big dye terminator, $0.5 \mu \mathrm{l} 0.125 \mu \mathrm{M}$ primer (forward or reverse) and $5.4 \mu \mathrm{l}$ water. The thermal profile used was: 35 cycles comprising $60 \mathrm{~s}$ at $96^{\circ} \mathrm{C}, 5 \mathrm{~s}$ at $50^{\circ} \mathrm{C}$, and $3 \mathrm{~min}$ at $60^{\circ} \mathrm{C}$. The 3500XL Genetic Analyzer (Applied Biosystems) was used for the Sanger sequencing method [20-22].

\section{Determination of HBV genotypes and sub-genotypes}

HBV genotypes were determined by comparing with preS/S gene sequences of the NCBI Web based HBV Genotyping Tool (http://www.ncbi.nlm.nih.gov/ projects/genotyping/ formpage.cgi) [23]. HBV DNA sequences were aligned with reference sequences using the CLUSTAL method (MedAlign, Lasergene, DNASTAR 
Inc., Madison, WI). Sequences were manually edited with the BioEdit Sequence Editor (version 7.2.5), and phylogenetic relationships were established by applying the neighbor-joining method [24]. To confirm reliability of the pairwise comparison and phylogenetic analysis, bootstrap resampling and reconstruction were carried out 1000 times. For determination of the sub-genotype, study sequences were aligned with published sequences representing all known HBV sub-genotypes. Multiple sequence alignment was performed using the built-in ClustalW integrated in MEGA X software [25]. Phylogenetic analysis of HBV sub-genotypes was carried out using the MEGA X software. Genetic distances were calculated using the Kimura two-parameter model, and phylogenetic trees were constructed by applying the Maximum Likelihood method. The nucleotide sequences obtained in this study have been deposited at the NCBI GenBank database (Accession numbers: MH816993-995 and MH925817-925683).

\section{Statistical analysis}

All statistical analyses were performed using the Statistical Program for Social Science Software (SPSS) 23.0 for Windows (SPSS Inc., Chigago IL., USA). Comparison between categorical variables was tested by the Chisquare test. Analysis of variance (ANOVA) was also performed to analyze the relationship of HBV genotype and HBV infection phase with age of the patients. A $P$-value (two tailed) of less than 0.05 is considered to be statistically significant. In this genotyping study, distribution of the HBV genotypes was compared among 5 geographical areas, such as central, east, north, south and western regions of Myanmar. Mandalay, Magway, Nay Pyi Taw, Bago, Ayeyarwady and Yangon regions were collectively described as the central area, Shan and Kayah states as the eastern area, Kachin state and Sagaing regions as the northern area, Mon and Kayin states and Tanintharyi region as the southern area, and Rakhine and Chin states as the western area. HBV subgenotype results were subsequently analyzed collectively.

\section{Results}

\section{Distribution of HBV genotypes among the study} population

All $353 \mathrm{HBsAg}$ positive serum samples also tested positive by HBV ELISA. Of the confirmed $353 \mathrm{HBsAg}$ positive samples, 153 (43.3\%) were PCR positive $(69$ males and 84 females, mean age $34.0 \pm 11.54$ years), and were further included for genotype analysis (Fig. 1). Three major genotypes $(\mathrm{C}, \mathrm{D}$ and $\mathrm{B})$ were found in this study population. The HBV genotype $C(n=102 ; 66.7 \%)$ was found to be the predominant circulating genotype $(p=0.002)$, followed by genotypes $\mathrm{D}(n=49 ; 32 \%)$ and $\mathrm{B}(n=2,1.3 \%)$ (Table 1$)$.

\section{Distribution of HBV genotypes in the five geographical areas}

The HBV genotypes were found differently distributed in the different regions of Myanmar (Table 2, Fig. 2).

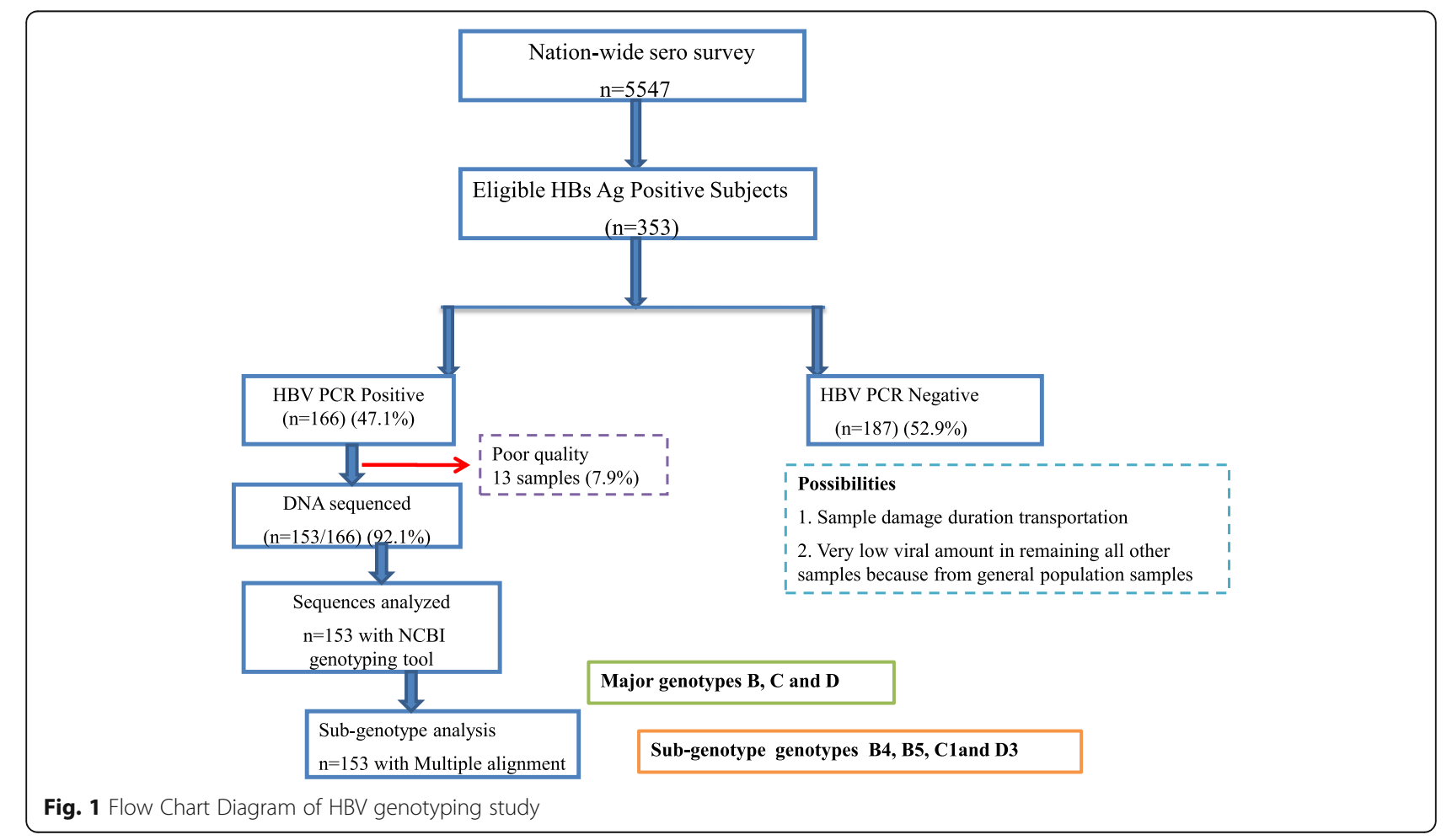


Table 1 Characteristics of subjects and Genotype and sub-genotypes distribution

\begin{tabular}{|c|c|c|c|c|}
\hline Characteristics & Genotype B & Genotype C & Genotype D & Significance \\
\hline $\begin{array}{l}\text { Number of subjects (\%) } \\
n=153(100 \%)\end{array}$ & $\begin{array}{l}2 \\
(1.3 \%)\end{array}$ & $\begin{array}{l}102 \\
(66.7 \%)\end{array}$ & $\begin{array}{l}49 \\
(32 \%)\end{array}$ & $P=0.002$ \\
\hline $\begin{array}{l}\text { Age (Mean } \pm \text { SD) } \\
34.0 \pm 11.4 \mathrm{Yr}\end{array}$ & $41.5 \pm 9.12$ & $33.84 \pm 11.72$ & $33.88 \pm 10.66$ & $\begin{array}{l}\mathrm{NS}^{\mathrm{b}} \\
P=0.065\end{array}$ \\
\hline $\begin{array}{l}\text { Gender (M/ F) } \\
(69 / 84)\end{array}$ & $2 / 0$ & $45 / 57$ & $22 / 27$ & $\begin{array}{l}N^{a}{ }^{a} \\
P=0.290\end{array}$ \\
\hline Sub-genotypes & $\begin{array}{l}2 \\
B 4, B 5\end{array}$ & $\begin{array}{l}3 \\
\mathrm{C} 1, \mathrm{C} 5, \mathrm{C} 7\end{array}$ & $\begin{array}{l}2 \\
\mathrm{D} 3, \mathrm{D} 6\end{array}$ & \\
\hline
\end{tabular}

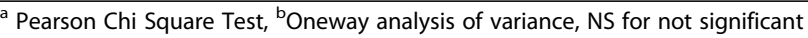

HBV genotype $\mathrm{C}$ was predominant in all areas, ranging from 61.7 to $91.7 \%$, except in the western area (41.2\%). Genotype B was found in two areas (north and central) with an occurrence of only $1.3 \%$ of HBV isolates. Genotype D was the major genotype (59\%) in the western region of Myanmar, which borders with India and Bangladesh. HBV genotype $\mathrm{C}$ was predominant in the 35 subjects examined from the eastern area, and was identified in 26 (74.3\%) subjects. Differential genotype distributions were observed in the western and eastern regions of Myanmar.

\section{HBV sub-genotypes in Myanmar}

Among the 102 genotype $\mathrm{C}$ identified, the distribution of sub-genotypes was found to be HBV sub-genotype C1 (90.2\%), followed by HBV sub-genotype C5 (5.9\%) and HBV sub-genotype C7 (3.9\%). In the total $49 \mathrm{HBV}$ genotype D samples, majority were clustered into the HBV sub-genotype D3 $(45,91.8 \%)$, with the remaining identified as HBV sub-genotype D6 (8.2\%). Only two HBV isolates were genotype $\mathrm{B}$ in our study population, belonging to sub-genotypes B4 and B5 (Table 2, Fig. 2).

Genotyping of the $153 \mathrm{HBV}$ isolates (Accession numbers: MH816993-995 and MH925817-925683) was determined by constructing a cladogram (Fig. 3). The test sequences were grouped with reference sequences (Additional file 1) according to their genotypes and subgenotypes. The genotypes of these sequences were also determined by the NCBI genotyping tool, which gave complete fidelity findings with the phylogenetic results.
Genotype D study sequences were clustered into subgenotype D3 by reference sequences of HBV subgenotypes D1 to D8 retrieved from the GenBank data base, together with genotype D study sequences, to construct phylogenetic tree by neighbor-joining.

method using the maximum composite likelihood method to calculate evolutional distance (Fig. 4); Genotype $C$ sequences were clustered into sub-genotypes $C 1$, $\mathrm{C} 5$ and $\mathrm{C7}$, as determined by the sub-genotype reference sequences (Fig. 5).

\section{Discussion}

HBV genotyping is important to clarify the route of infection and virulence of the virus. In particular, examination of sequence diversity among different isolates of the virus is important, since variants may differ in their patterns of serological reactivity, replication of the virus, activity of liver disease, prognosis, and response to treatment. A total of 353 subjects from the general population of Myanmar having hepatitis B infection were enrolled in this study. There is no previously available information regarding the regional prevalence of $\mathrm{HBV}$ genotypes from Myanmar. In a multi-country study on chronic liver disease patients, the most common genotype identified in Myanmar was type $C$ [21, 26, 27]. In the current study findings, the major genotype was $\mathrm{HBV}$ genotype $\mathrm{C}$, which is in accordance with previous $\mathrm{HBV}$ studies in Myanmar. HBV genotypes are known to have a divergent geographic distribution. The predominant genotypes reported from Southeast Asian countries were

Table 2 Area- wise distribution of HBV genotypes in Myanmar

\begin{tabular}{|c|c|c|c|c|c|c|}
\hline \multirow{2}{*}{$\begin{array}{l}\text { HBV } \\
\text { Genotypes }\end{array}$} & \multirow{2}{*}{$\begin{array}{l}\text { Total } \\
\text { Subjects }\end{array}$} & \multicolumn{5}{|l|}{ Area } \\
\hline & & $\begin{array}{l}\text { Southern Area (Mon, } \\
\text { Tanintharyi, Kayin states) }\end{array}$ & $\begin{array}{l}\text { Western Area (Chin\& } \\
\text { Rakhine states) }\end{array}$ & $\begin{array}{l}\text { Eastern } \\
\text { Area (Shan\& } \\
\text { Kaya States) }\end{array}$ & $\begin{array}{l}\text { Northern } \\
\text { Area (Kachin states\& } \\
\text { Sagaing region) }\end{array}$ & $\begin{array}{l}\text { Central } \\
\text { Area (Mandalay, Magway, Nay PyiTaw, } \\
\text { Ayeyarwaddi, Bago, Yangon) }\end{array}$ \\
\hline & & $(n=29), n \%$ & $(n=17), n \%$ & $(n=35), n \%$ & $(n=12), n \%$ & $(n=60), n \%$ \\
\hline C & 102 & $21(72.4 \%)$ & $7(41.2 \%)$ & $26(74.3 \%)$ & $11(91.7 \%)$ & 37 (61.7\%) \\
\hline D & 49 & $8(27.6 \%)$ & 10 (58.8\%) & $9(25.7 \%)$ & 0 & 22 (36.7\%) \\
\hline \multirow[t]{2}{*}{ B } & 2 & 0 & 0 & 0 & $1(8.3 \%)$ & $1(1.6 \%)$ \\
\hline & 153 & & NS & & & \\
\hline
\end{tabular}




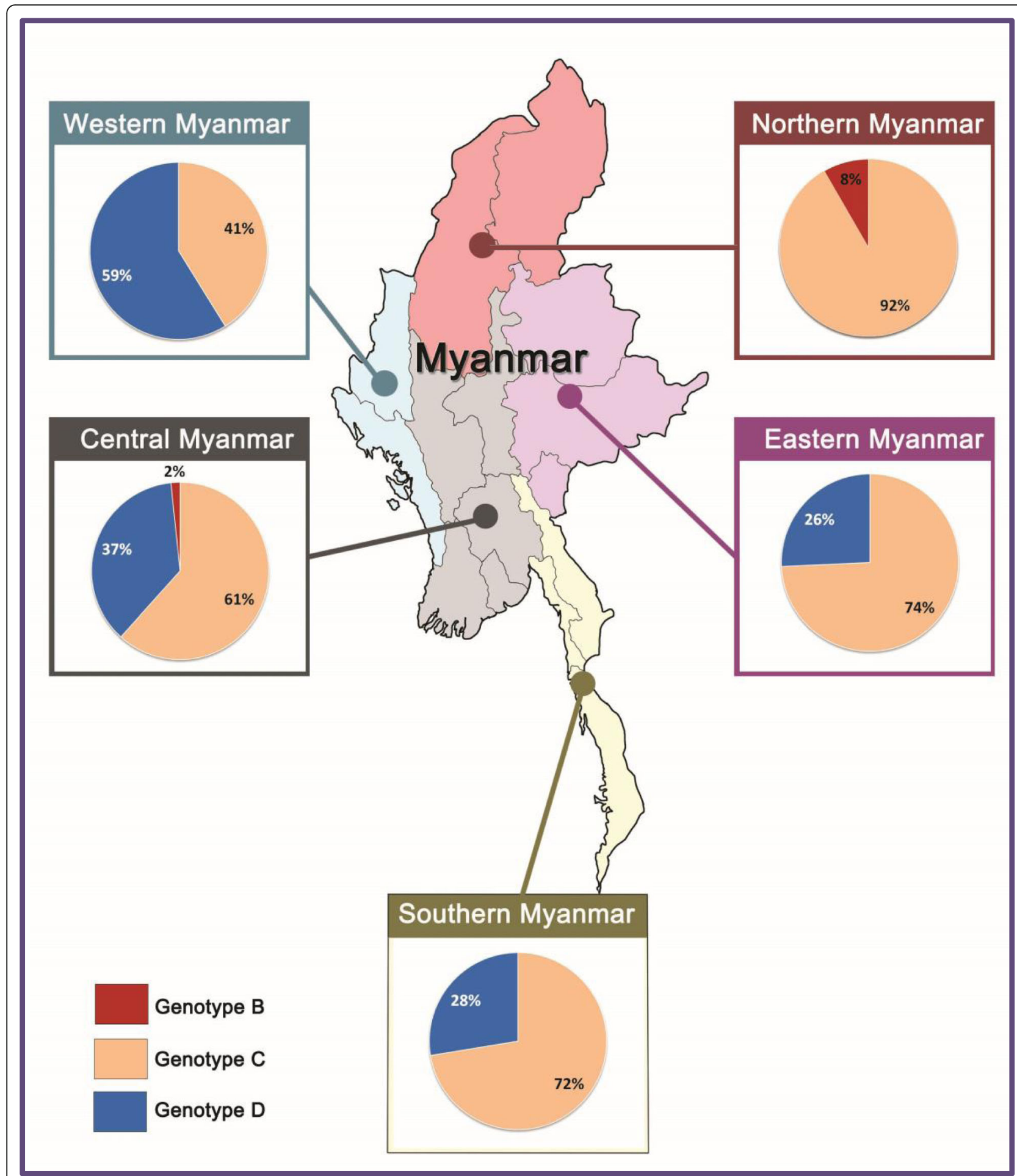

Fig. 2 HBV genotype distribution in five geographical regions of Myanmar

genotype $\mathrm{C}$ from Thailand, and genotypes $\mathrm{C}$ and $\mathrm{B}$ from Indonesia [28]. In China, HBV genotype $C$ and $B$ were found to be predominant among the Negrito and Mongoloid tribes. Moreover, HBV genotype A and D were the most prevalent in India [14]. In this study, HBV genotype $\mathrm{D}$ is the predominant genotype in the western area of Myanmar, and type $\mathrm{C}$ was mostly found in the eastern region bordering China and Thailand, as well as 


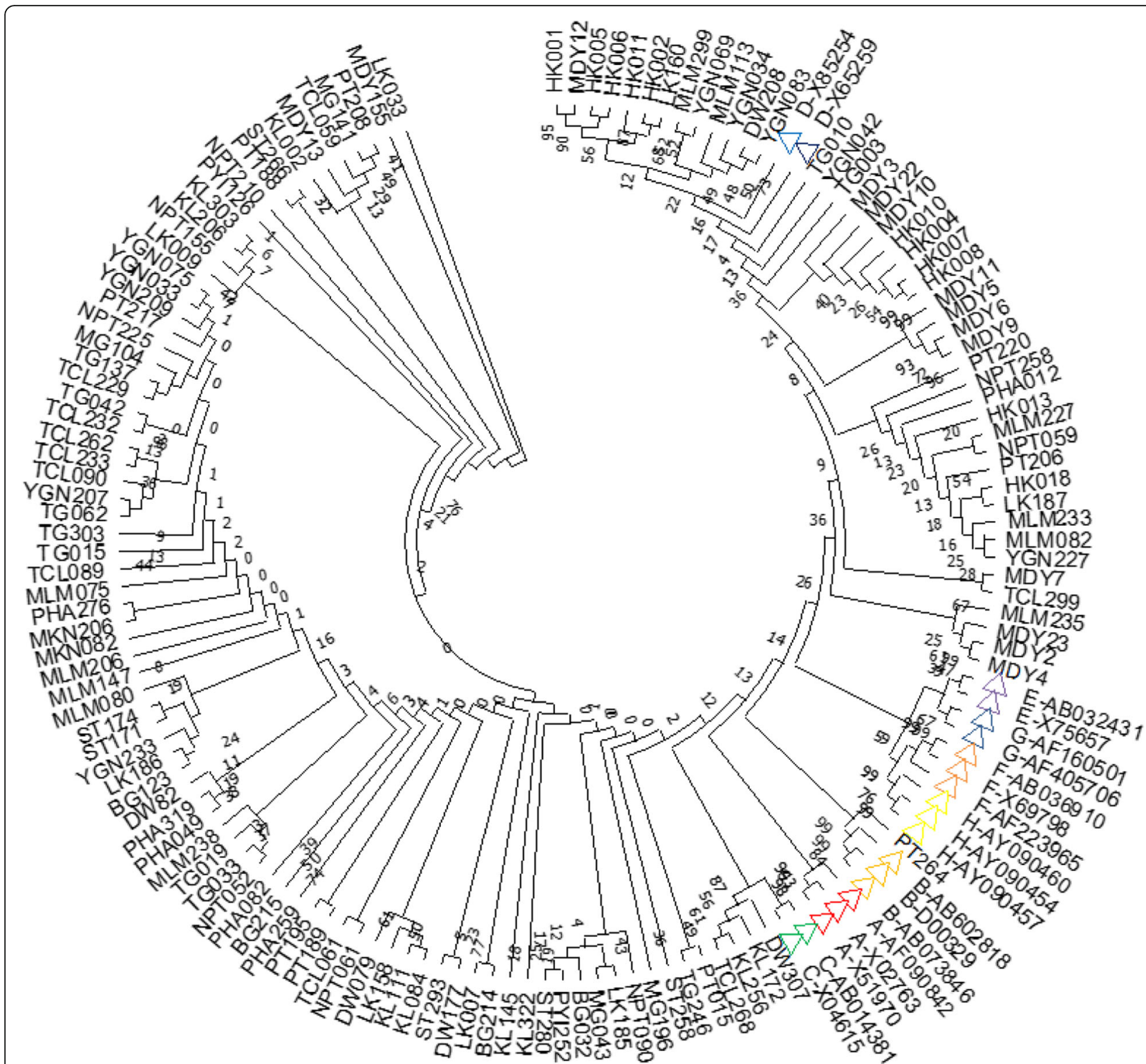

Fig. 3 Cladogram of $153 \mathrm{HBV}$ sequences with NCBI major genotype reference sequences. The phylogenetic tree was constructed using $578 \mathrm{bp}$ nucleotide sequences (2860-222) PreS1/ PreS2 region of the reference genome of hepatitis B genotype representing the standard genotypes throughout the world. Phylogenetic analysis by neighbour-joining method with bootstrap test of 1000 replicates and maximum composite likelihood model was applied. Color triangles show the different reference major genotypes from the NCBI GenBank

in the central and southern areas, indicating that genotype $\mathrm{C}$, the major genotype of Mongoloid tribes, might be the causative agent of infection.

Moreover, Paraskevis et al. [29] reported that genotype $\mathrm{C}$ is the oldest HBV genotype and has the highest numbers of sub-genotypes, viz., C1-C16 [30, 31], reflecting the long duration of its endemicity in humans. In this study, we determined a few sub-genotypes circulating in different parts of Myanmar, with the majority being subgenotype $\mathrm{C} 1$. This was similar to the findings of $\mathrm{HBV}$ sub-genotypes found in United States-bound refugees from Myanmar, and adult immigrants to Australia from
Myanmar [32, 33]. Considering the sub-genotypes of HBV genotype $C$, at least two subtypes are found in Asia: HBV genotype $\mathrm{C} 1$ was found only in Southeast Asia including Vietnam, Myanmar and Thailand, while HBV genotype C2 was found in east Asia including Japan, Korea and China [27]. In this study, most genotypes of $C$ were found to belong to the sub-genotype $C 1$, and was equally distributed throughout Myanmar. A low percentage of strains from the study subjects showed sub-genotypes $\mathrm{C} 5$ and $\mathrm{C} 7$, mainly in the central region of Myanmar. Moreover, this result was quite similar to the previous study on 15 isolates from hepatitis carriers, 


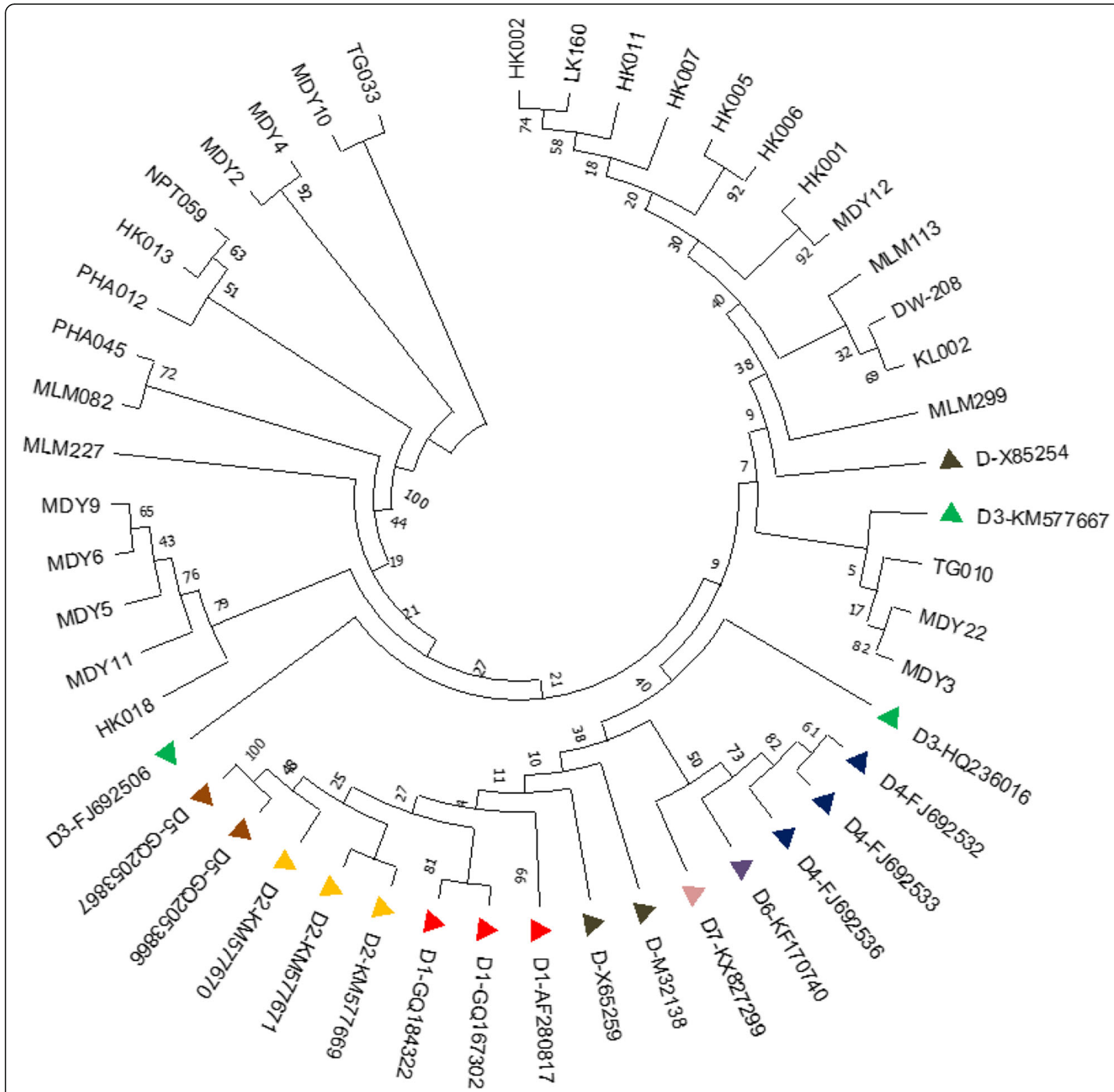

Fig. 4 Cladogram of HBV sub-genotypes of genotype D. Phylogenetic tree was constructed using 578 bp nucleotide sequences (2860-222) PreS1/ PreS2 region in the MEGA X, using the Maximum Likelihood method with bootstrap test of 1000 replicates and Kimura two parameter model. GenBank reference sequences are shown as HBV sub-genotype and accession number. Study sequences were designed by study number

which showed that all HBV isolates were subgenotypes C1 [18], and seemed to be present for quite a long time in Myanmar [26]. Presence of multiple sub-genotypes $\mathrm{C}$ indicate that HBV has proliferated since long in Myanmar.

According to the recent system and comparative analysis of the sub-genotype $\mathrm{D}$, at least six variants (D1D6) have been classified. Of these, the sub-genotype D3 was most frequently determined in this study, followed by D6 (Table 1). Few incidences of genotype D were reported in previous clinical case studies, and we believe this is the first report on prevalence of HBV genotype D, sub-genotype D3 in Myanmar [16]. However, the prevalence of genotype D was higher than previous findings, which might be due to frequent international travels of individuals, and also due to migration. In addition, in Myanmar, there is no large-scale study of HBV genotypes with application of sequencing for reliable data, and the outcome may also be associated with regional variation. Genotype D was mostly found in the western 


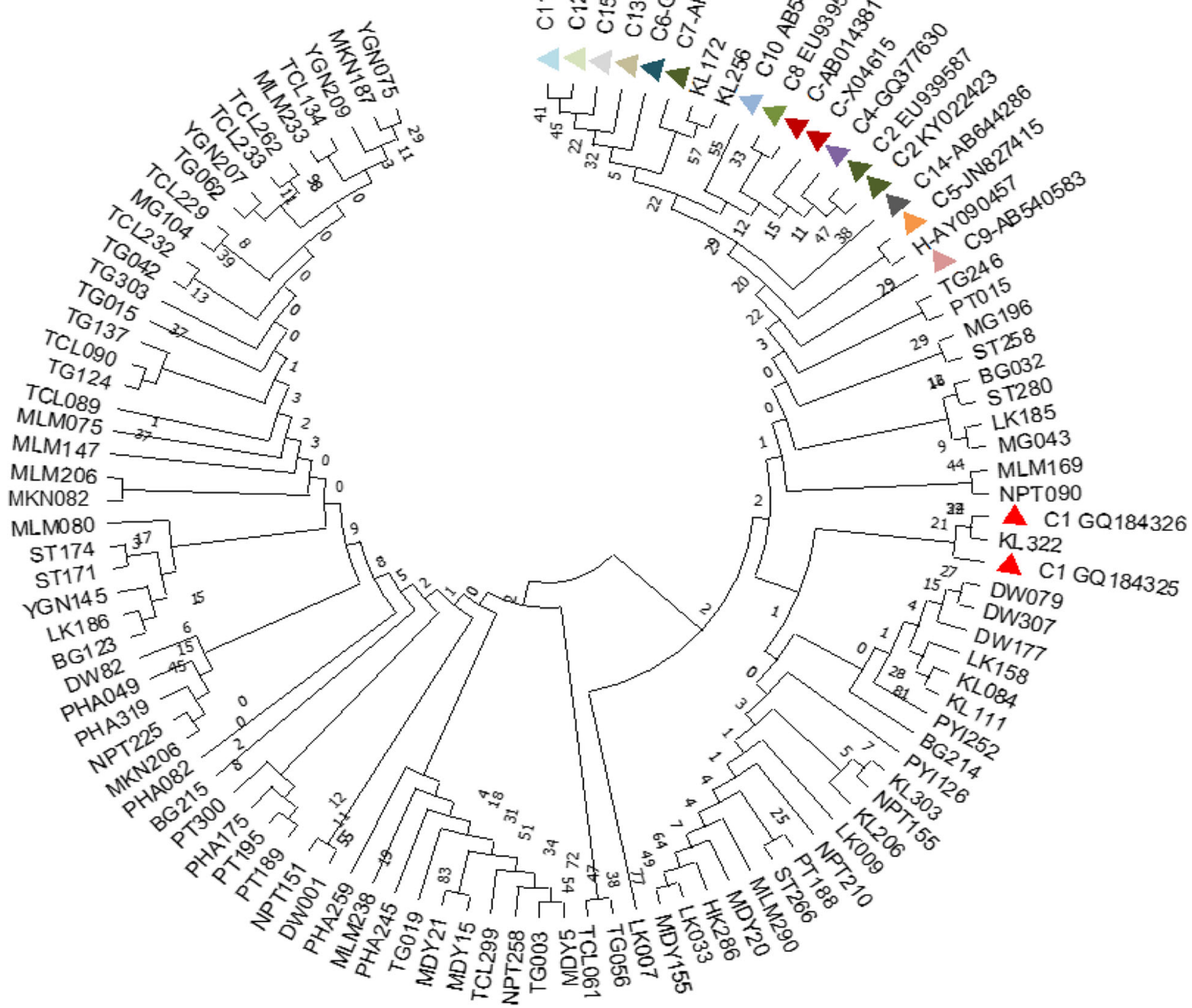

Fig. 5 Cladogram of HBV sub-genotypes of genotypes C. Phylogenetic tree was constructed using 578 bp nucleotide sequences (2860-222) PreS1/ PreS2 region in MEGA X using the neighbor-joining method with bootstrap test of 1000 replicates and maximum composite likelihood model. GenBank reference sequences are shown as HBV sub-genotype and accession number. Study sequences were designed by study number

region of Myanmar which is quite near India and Bangladesh, where genotype $\mathrm{D}$ is more prevalent $[34,35]$.

In the current study, a relatively lower proportion (1.3\%) of the study population tested positive for genotype $B$, sub-genotype B4 and B5. A previous study in the Yangon region had also reported the absence of $B$ genotype in their study population [16]; however, inconsistent findings were reported in a study of Australian adult immigrants from Myanmar, where $10.5 \%$ of the study population were characterized as genotype B [33]. In our study, only $1.3 \%$ of the study population was found to have the HBV genotype $B$, thereby indicating that a low prevalence of this genotype was circulating in the country.

It has been reported that the geographical distribution of HBV genotypes might be related to the route of exposure to infection. For example, HBV genotype B and $\mathrm{C}$ were more common in highly endemic regions like Asia and Africa in which perinatal or vertical exposure is an important route of viral transmission. Other genotypes were primarily observed in regions of horizontal exposure [11-13, 36, 37]. Therefore, HBV genotype distribution can be provided as epidemiological evidence 
for investigating viral acquisition and the geographical scattering pattern of HBV [11-13, 36, 37]. In the current study, genotype $\mathrm{C}$ was predominant in most regions of Myanmar, and vertical transmission seems to be the main mode of transmission. As there is no documented study on the transmission pattern of HBV in Myanmar, further studies are required for verifying this hypothesis.

Because of frequent international travels and human migration across countries, introduction of new HBV genotypes to a community might have far reaching effects, including recombination between genotypes [36] or replacement of one genotype by another [38]. Compared to the HBV genotype $\mathrm{B}$, the genotype $\mathrm{C}$ is associated with delayed hepatitis $B$ e antigen ( $\mathrm{HBeAg}$ ) seroconversion [38], more-active hepatitis [39], lower response to antiviral therapy [40], more advanced liver disease, and a higher risk of hepatocellular carcinoma [41].

In addition, we found that $102 / 153$ subjects (66.7\%) of the study population are genotype $C$ isolates. Thus, the patients infected with genotype $\mathrm{C}$ need to be carefully monitored to assess their future clinical outcomes. Particularly, sub-genotype $\mathrm{C} 1$ is documented to have an increased tendency for the development of cirrhosis and hepatocellular carcinoma ( $\mathrm{HCC}$ ), especially in patients over 50 years of age [42-44]. On the other hand, genotype $\mathrm{B}$ patients have higher rates of $\mathrm{HBeAg}$ seroconversion, and HCC has been detected in younger patients $[42,45,46]$.

\section{Conclusions}

HBV genotype $\mathrm{C}$, sub-genotype $\mathrm{C} 1$ is the most predominant variant in Myanmar and is distributed throughout the states and regions, whereas genotype HBV genotype D (sub-genotype D3 and D6) is predominantly found at the Myanmar-India border. This study provides information on the geographical distribution of viral hepatitis $B$ genotypes in Myanmar, and can contribute towards establishing Hepatitis B control measures in Myanmar.

\section{Supplementary information}

Supplementary information accompanies this paper at https://doi.org/10. 1186/s12879-020-05269-z.

Additional file 1.

\section{Abbreviations}

HBV: Hepatitis B virus; HBsAg: Hepatitis B surface Antigen; ICT: Immunochromatographic test; PCR: Polymerase chain reaction; NCBI: National Centre for Biotechnology Information; WHO: World Health Organization; RT: Reverse transcriptase; HBeAg: Hepatitis B envelope antigen; PSU: Primary Sampling Unit; SSU: Secondary Sampling Unit

\section{Acknowledgments}

The authors would like to thank Korea International Co-operation Agency (KOICA) and National Research Foundation of Korea for partial financial support, and the Clinton Health Care Foundation for permission to continue molecular epidemiology study from the Nationwide sero-survey. The authors also would like to thank Dr. Wah Wah Aung for editing the manuscript, and Dr. Myat Htut Nyunt for helping sequence analysis.

\section{Authors' contributions}

YYK: sample collection, proposal writing, study design, study supervision, performing sequencing work, data compilation and analysis and manuscript writing. AAL and MMT: participated in proposal writing, sample collection. HOMS: sample collection and performing sequencing work. KSA: proposal writing, study design, study supervision. HMT: proposal writing, study design, study supervision. KTA: performing sequencing. KZT- HMT: proposal writing, study design, study supervision. $\mathrm{HJH}$ : performing sequence analysis. JHC: study supervision, manuscript writing and review. All authors have read and approved the final manuscript.

\section{Funding}

This research was supported by the Basic Science Research Program through the National Research. Foundation of Korea (NRF) funded by the Ministry of Education, Science and Technology (2020R1F1A104973111). There was no role of the funding body in study design, data collection, and analysis.

\section{Availability of data and materials}

The partial sequences of $153 \mathrm{HBV}$ isolates have been submitted to the Gene Bank. The accession numbers of this study isolates are MH816993-995 and MH925817-925863. Original data may be obtained by email to corresponding author

\section{Ethics approval and consent to participate}

This study was approved by the Ethics Review Committee of the Department of Medical Research, Republic of Union of Myanmar. The approval number is 22/Ethics 2015, dated 25.3.2015. Written informed consents were obtained from the study participants who were 16 years and above, and from the parents/guardians of the study participants who were under 16 years. The study procedure strictly followed the Declaration of Helsinki for research including human beings.

Consent for publication

Not relevant

\section{Competing interests}

The authors declare that they have no competing interests.

\section{Author details}

${ }^{1}$ Advanced Molecular Research Centre, Department of Medical Research, Republic of Union of Myanmar, Yangon, Myanmar. ${ }^{2}$ Department of Medical Research, Republic of Union of Myanmar, Yangon, Republic of Union of Myanmar. ${ }^{3}$ Department of Molecular Biology, Pusan National University, Busan 46241, Republic of Korea.

Received: 21 June 2019 Accepted: 16 July 2020

Published online: 24 August 2020

\section{References}

1. WHO Fact Sheet N 204. http://www.who.int/mediacentre/factsheets/fs204/ en/. Accessed $27^{\text {th }}$ June, 2018.

2. World Health Organization. Global Hepatitis Report 2017. Geneva: WHO; 2017.

3. Lwin AA, Aye KS, Htun MM, Kyaw YY, ZawKK ATT, Kyaw MP, Kyi KP, Thant KZ. Sero-prevalence of viral hepatitis $B$ and $C$ viral infection in Myanmar: National and regional survey in 2015. MHSRJ. 2017;29(3):167-75.

4. Utsumi T, Yano Yand Hotta H. Molecular epidemiology of hepatitis B virus in Asia. World J Med Genetics. 2014:4(2):19-26.

5. Ganem D and Prince A.M. Hepatitis B virus infection-natural history and clinical consequences. NEngl J Med 2004, 350:1118-1119.

6. Nassal M. Hepatitis B virus morphogenesis. Curr Top Microbiol Immunol. 1996;214:297-337

7. Norder H, Courouce AM, Coursaget P, Echevarria JM, Lee SD, Mushahwar IK Robertson BH, Locarnini S, Magnius LO. Genetic diversity of hepatitis B virus strains derived worldwide: genotypes, subtypes, and HBs Ag subtypes. Intervirology. 2004;47(6):289-309. 
8. Stuyver L, De Gendt S, Van Geyt C, Zoulim F, Fried M, Schinazi RF, et al. A new genotype of hepatitis $B$ virus: complete genome and phylogenetic relatedness. J Gen Virol. 2000;81:67-74.

9. Norder H, Hammas B, Lofdahl S, Courouce AM, Magnius LO. Comparison of the amino acid sequences of nine different serotypes of hepatitis $B$ surface antigen and genomic classification of the corresponding hepatitis $B$ virus strains. J Gen Virol. 1992;73(Pt 5):1201-8.

10. Magnius LO, Norder H. Subtypes, genotypes and molecular epidemiology of the hepatitis B virus as reflected by sequence variability of the S-gene. Intervirology. 1995;38(1-2):24-34.

11. Sakamoto T, Tanaka Y, Orito E, Co J, Clavio J, Sugauchi F, Ito K, Ozasa A, Quino A, Ueda R, et al. Novel subtypes (sub-genotypes) of hepatitis B virus genotypes B and C among chronic liver disease patients in the Philippines. J Gen Virol. 2006;87:1873-82.

12. Schaefer S. Hepatitis B virus taxonomy and hepatitis B virus genotypes. World J Gastroenterol. 2007;13:14-21.

13. Allain JP. Epidemiology of hepatitis B virus and genotype. J Clin Virol. 2006; 36(Suppl 1):S12-7.

14. Thippavazzula R, Mogili C, Chandra M, Khaja MN, Habeeb MA, Habibullah CM. Prevalent HBV genotypes and subtypes in a south Indian population. J Clin Virol. 2006;37(1):58-64.

15. Oo AW, Kim CJ, Shin KS, Oo KM, Kyaw A, Kyi KP, Khin M. Hepatitis B surface antigen subtypes in Yangon, Myanmar. MHSRJ. 2012;24(1):30-4.

16. Nakai K, Win KM, Oo SS, Arakawa Y, Abe K. Molecular characteristic-based epidemiology of hepatitis B, C, and E viruses and GB virus C/ hepatitis $G$ virus in Myanmar. J Clin Microbiol. 2001;39(4):1536-9.

17. Sa-Nguanmoo P, Tangkijvanich P, Thawornsuk N, Vichaiwattana P, Prianantathavorn K, Theamboonlers A, Tanaka Y, Poovorawan Y. Molecular epidemiological study of hepatitis B virus among migrant workers from Cambodia, Laos, and Myanmar to Thailand. J Med Virol. 2010;82:1341-9.

18. Latt AZ, Win NN, Aye KT, Thu HM, Kyaw YY, Thant KZ. Whole genome sequencing of hepatitis $B$ virus (HBV) strains from Myanmar. J Bio Engineer RR. 2017:4(2):01-6.

19. Tanwar S, Dusheiko G. Is there any value to hepatitis B genotype analysis? Curr Gastroenterol. 2015;14(1):37-46.

20. Kyaw YY, Win AA, Cho HK, Htun WM, Aye KT, Win NN, Thu HM, Cheong JH. Sequencing on sub-genomic fragment (Pre-S region) for detection of hepatitis B genotypes in Myanmar. $43^{\text {rd }}$ Myanmar Health Research Congress: Programme and abstract; 2015. p. 87.

21. Kyaw YY, Lwin AA, Soe HOM, Lwin OM, Cho HK, Aye KS, Chang CHL, Cheong JH. Usefulness of dried blood samples for detection, quantification, and molecular characterization of HBV DNA in Myanmar. Ann Lab Med. 2016;36(Supplement1):S.15.

22. Kyaw YY, Cho HK, Win AA, Soe HOM, Lwin OM, Kim SY, Thu HM, Seong M, Cheong $\mathrm{JH}$. Sequencing on sub-genomic fragment (Pre-S region) for detection of hepatitis B genotypes among reproductive age group women in Myanmar. In: International HBV meeting: the molecular biology of hepatitis B viruses, Programme and abstract, vol. 199; 2016.

23. Rozanov M, Plikat U, Chappey C, Kochergin A, Tatusova T. A web-based genotyping resource for viral sequences. Nucleic Acids Res. 2004;32:W654-9.

24. Hall TA. BioEdit: a user-friendly biological sequence alignment editor and analysis program for Windows 95/98/NT. Nucleic Acids Symp Ser. 41:95-8.

25. Kumar S, Stecher G, Li M, Knyaz C, Tamura K. MEGA X: Molecular evolutionary genetic analysis across computing platforms. Mol Biol Evol. 2018:35:157-1549.

26. Huy $\Pi$, Ushijima H, Win KM, Luengrojanakul P, Shrestha PK, Zhong ZH, Smirnov AV, Taltavull TC, Sata T, Abe K. High prevalence of hepatitis B virus pre-S mutant in countries where it is endemic and its relationship with genotype and chronicity. J Clin Microbiol. 2003;41:5449-55.

27. Huy TT, Ushijima H, Quang VX, Win KM, Luengrojanakul P, Kikuchi K, Sata T, Abe K. Genotype C of hepatitis B virus can be classified into at least two subgroups. J Gen Virol. 2004;85(2):283-92.

28. Utama A, Octavia TI, Dhenni R, Miskad UA, Yusuf I, Tai S. Hepatitis B virus genotypes/ subgenotypes in voluntary blood donors in Makassar, Sulawesi S, Indonesia. Virol J. 2009;6:128. https://doi.org/10.1186/1743422x-6-128.

29. Paraskevis D, Magiorkinis G, Magiorkinis E, Ho SY, Belshaw R, Allian JP, Hatzakis A. Dating the origin and dispersal of hepatitis $B$ virus infection in human and primates. Hepatology. 2013;57(3):908-16.

30. Mulyanto PP, Depamede SN, Wahyono A, Jirintai S, Nagashima S, Takahashi M, Nishizawa T, Okamoto H. Identification of four novel subgenotypes (C13-C16) and two inter-genotypic recombinants (C12/G and (13/B3) of hepatitis B virus in Papua province, Indonesia. Virus Res. 2012;163:129-40.

31. Shi W, Zhu C, Zheng W, Ling C, Carr MJ, Higgins DG, Zhang Z. Subgenotyping of genotype $C$ hepatitis B virus: correcting misclassifications and identifying a novel subgenotype. PLoS One. 2012;7:e47271.

32. Mixson-Hayden T, Lee D, Ganova-Raeva L, Drobeniuc J, Stauffer WM, Teshale E, Kamili S. Hepatitis B virus and hepatitis C virus infections in United Statesbound refugees from Asia and Africa. Am J Trop Med Hyg. 2014;90:1014-20.

33. Schulz TR, Edwards R, Thurnheer MC, Yuen L, Littlejohn M, Revill P, Chu M, Tanyeri F, Wade A, Biggs BA, et al. Hepatitis B among immigrants from Myanmar: Genotypes and their clinical relevance. J Med Virol. 2017;90:271-6.

34. Chattopadhyay S, Das BC, Kar P. Hepatitis B virus genotypes in chronic liver disease patients from New Delhi, India. World I Gastroenterol. 2006;12: 6702-6.

35. Rahman MA, Hakim F, Ahmed M, Ahsan CR, Nessa J, Yasmin M. Prevalence of genotypes and sub-types of hepatitis B viruses in Bangladeshi population. Springer Plus. 2016;5:278

36. Sugauchi F, Orito E, Ichida T, Kato H, Sakugawa H, Kakumu S, Ishida T, Chutaputti A, Lai CL, Ueda R, Miyakawa Y, Mizokami M. Hepatitis B virus of genotype B with or without recombination with genotype cover the precore region plus the core gene. J Virol. 2002;76:5985-92.

37. Sunbul M. Hepatitis B virus genotypes: Global distribution and clinical importance. World J Gastroenterol. 2014;20(18):5427-34.

38. Chu CJ, Hussain M, Lok AS. Hepatitis B virus genotype B is associated with earlier HBeAg sero-conversion compared with hepatitis B virus genotype $C$ Gastroenterology. 2002;122:1756-62.

39. Chan HL, Wong ML, Hui AY, Hung LC, Chan FK, Sung JJ. Hepatitis B virus genotype $C$ takes a more aggressive disease course than hepatitis $B$ virus genotype B in hepatitis B e antigen positive patients. J Clin Microbiol. 2003; 41(3):1277-9.

40. Wai CT, Chu CJ, Hussain M, Lok AS. HBV genotype B is associated with better response to interferon therapy in $\mathrm{HBeAg}(+)$ chronic hepatitis than genotype C. Hepatology. 2002;36:1425-30.

41. Chan HL, Hui AY, Wong ML, Tse AM, Hung LC, Wong WW, Sung JJ. Genotype C hepatitis B virus infection is associated with an increased risk of hepatocellular carcinoma. Gut. 2004;53(10):1494-8.

42. Da Silva Conde, S. R S., Pinhero LM, de Lemos JAR, Demachki S, de Araujo MT, et al. prevalence of genotypes and sub-genotypes of the hepatitis B virus in a population of the Brazilian Amazon region (Pará state). J Antivir Antiretrovir 2013; 5: 108-112.

43. Wang Z, Huang Y, Wen S, Zhou B, Hou J. Hepatitis B virus genotypes and subgenotypes in China. Hepatol Res. 2007;37:S36-41.

44. You J, Sriplung H, Geater A, Chongsuvivatwong V, Zhuang L, et al. Hepatitis $B$ virus DNA is more powerful than $H B e A g$ in predicting peripheral Tlymphocyte subpopulations in chronic HBV-infected individuals with normal liver function tests. World J Gastroenterol. 2008;14:3710-8.

45. Kao JH, Chen PJ, Lai MY, Chen DS. Hepatitis B genotypes correlate with clinical outcomes in patients with chronic hepatitis B. Gastroenterology. 2000;118:554-9.

46. Ni YH, Chang MH, Wang KJ, Hsu HY, Chen HL, et al. Clinical relevance of hepatitis B virus genotype in children with chronic infection and hepatocellular carcinoma. Gastroenterology. 2004;127:1733-8.

\section{Publisher's Note}

Springer Nature remains neutral with regard to jurisdictional claims in published maps and institutional affiliations.

\section{Ready to submit your research? Choose BMC and benefit from:}

- fast, convenient online submission

- thorough peer review by experienced researchers in your field

- rapid publication on acceptance

- support for research data, including large and complex data types

- gold Open Access which fosters wider collaboration and increased citations

- maximum visibility for your research: over $100 \mathrm{M}$ website views per year

At $\mathrm{BMC}$, research is always in progress.

Learn more biomedcentral.com/submissions 